\title{
Time dependent response of daunorubicin on cytotoxicity, cell cycle and DNA repair in acute lymphoblastic leukaemia
}

Hussain Mubarak Al-Aamri, Heng Ku, Helen R. Irving ${ }^{*}$ De, Joseph Tucci, Terri Meehan-Andrews and Christopher Bradley

\begin{abstract}
Background: Daunorubicin is commonly used in the treatment of acute lymphoblastic leukaemia (ALL). The aim of this study was to explore the kinetics of double strand break (DSB) formation of three ALL cell lines following exposure to daunorubicin and to investigate the effects of daunorubicin on the cell cycle and the protein kinases involved in specific checkpoints following DNA damage and recovery periods.

Methods: Three ALL cell lines CCRF-CEM and MOLT-4 derived from T lymphocytes and SUP-B15 derived from B lymphocytes were examined following $4 \mathrm{~h}$ treatment with daunorubicin chemotherapy and 4,12 and $24 \mathrm{~h}$ recovery periods. Cell viability was measured via MTT (3-(4,5-dimethylthiazol-2-yl)-2-5 diphenyltetrazolium bromide) assay, reactive oxygen species (ROS) production by flow cytometry, double stranded DNA breaks by detecting $\mathrm{YH} 2 \mathrm{AX}$ levels while stages of the cell cycle were detected following propidium iodide staining and flow cytometry. Western blotting was used to detect specific proteins while RNA was extracted from all cell lines and converted to cDNA to sequence Ataxia-telangiectasia mutated (ATM).

Results: Daunorubicin induced different degrees of toxicity in all cell lines and consistently generated reactive oxygen species. Daunorubicin was more potent at inducing DSB in MOLT-4 and CCRF-CEM cell lines while SUP-B15 cells showed delays in DSB repair and significantly more resistance to daunorubicin compared to the other cell lines as measured by $\mathrm{YH} 2 \mathrm{AX}$ assay. Daunorubicin also causes cell cycle arrest in all three cell lines at different checkpoints at different times. These effects were not due to mutations in ATM as sequencing revealed none in any of the three cell lines. However, p53 was phosphorylated at serine 15 only in CCRF-CEM and MOLT-4 but not in SUP-B15 cells. The lack of active p53 may be correlated to the increase of SOD2 in SUP-B15 cells.

Conclusions: The delay in DSB repair and lower sensitivity to daunorubicin seen in the B lymphocyte derived SUPB15 cells could be due to loss of function of p53 that may be correlated to increased expression of SOD2 and lower ROS production.
\end{abstract}

Keywords: Ataxia-telangiectasia mutated (ATM), DNA double strand breaks (DSB), $\mathrm{YH} 2 \mathrm{AX}, \mathrm{p} 53$, Reactive oxygen species (ROS), Superoxide dismutase (SOD2)

\footnotetext{
* Correspondence: h.irving@latrobe.edu.au

Department of Pharmacy and Applied Sciences, La Trobe Institute for

Molecular Science (LIMS), La Trobe University, P.O. Box 199, Bendigo, Victoria,

Australia
}

(c) The Author(s). 2019 Open Access This article is distributed under the terms of the Creative Commons Attribution 4.0 International License (http://creativecommons.org/licenses/by/4.0/), which permits unrestricted use, distribution, and reproduction in any medium, provided you give appropriate credit to the original author(s) and the source, provide a link to the Creative Commons license, and indicate if changes were made. The Creative Commons Public Domain Dedication waiver (http://creativecommons.org/publicdomain/zero/1.0/) applies to the data made available in this article, unless otherwise stated. 


\section{Background}

Daunorubicin is an anthracycline antibiotic that is widely used in treating acute leukaemias [1]. Proposed mechanisms of anthracycline action have included: inhibition of synthesis of macromolecules through intercalation of daunorubicin into DNA strands [2, 3], interaction with molecular oxygen to produce reactive oxygen species (ROS), topoisomerase II inhibition and the formation of DNA adducts [4]. There is good evidence for all these pathways and the mechanism of action of the anthracyclines is likely to be multi-modal. The type of toxic lesions that generally results from daunorubicin treatment are DNA double strand breaks (DSB). The occurrence of DSB activates PI3K-like kinases such as Ataxia-telangiectasia mutated (ATM) [5]. ATM exists as an inactive dimer and undergoes autophosphorylation and monomerisation in response to DNA DSB [6]. Activated ATM phosphorylates histone $\mathrm{H} 2 \mathrm{AX}(\mathrm{H} 2 \mathrm{AX})$ at Ser139 residues of the carboxyl terminus to form $\gamma \mathrm{H} 2 \mathrm{AX}$ around the DNA-DSB. A large number of $\gamma \mathrm{H} 2 \mathrm{AX}$ molecules form around the DSB to create a focus point where various DNA repair and checkpoint proteins accumulate that facilitate DNA-DSB repair [7]. In response to DNA DSB, ATM initiates repair by either non-homologous end joining (NHEJ) or homologous recombination (HR) though the factors controlling which pathway is chosen are not well understood [8]. A common outcome of both pathways is phosphorylation of the tumour suppressor gene, protein 53 (p53), which plays a pivotal role in the cellular response to damage as p53 regulates numerous cellular responses, including cell cycle arrest and apoptosis as well as upregulation of anti-oxidant proteins such as manganese-containing superoxide dismutase (SOD2 or MnSOD) [9].

Phosphorylation of p53 is an essential factor for the activation of key cell cycle checkpoints that leads to a delayed cell cycle progression, resulting in a reversible arrest at the G1/S cell cycle checkpoint [10] and is also involved in the arrest of the G2/M checkpoint [11]. The activation of these checkpoints allows more time for DNA repair mechanisms to be initiated to maintain genomic integrity [10].

Increased levels of ROS following daunorubicin treatment can directly activate ATM in vitro [12]. It is proposed that ROS activates ATM by promoting the formation of disulphide bridges, and thus stabilising the ATM dimer, rather than forming a monomer as follows activation by DSBs. Since activated ATM remains as a dimer, ATM may engage a different set of substrates and thus different cellular responses. While there is subsequent downstream activation of p53 and other proteins activated by DSB, the other downstream targets of ATM activated by ROS are thought to differ substantially [12]. This could have potential effects on cell cycle arrest and the initiation of apoptosis as well as cellular redox homeostasis.

The process of lymphoid tumourigenesis often involves alterations to the ATM gene resulting in ATM deficient cells which are more sensitive to oxidative stress and are likely to undergo altered DNA repair and apoptotic pathways. We have chosen to limit our study to acute lymphoblastic leukaemia (ALL) lines as daunorubicin is widely used in the treatment of this leukaemia [13]. Little is known about the ATM sequence in ALL cell lines used in medical research. One of the aims of this study was to explore potential functional mutations in ATM that may affect how cells handle chemotherapy treatment. To this end, the ATM coding sequences in T-lymphoblast derived CCRF-CEM and MOLT-4 cells and B-lymphoblast derived SUP-B15 cells were analysed through Sanger sequencing.

Following daunorubicin treatment, activation of ATM occurs via different mechanisms. Firstly, ATM activation by DSB involves autophosphorylation at Ser1981 and monomerization of the native dimer, and subsequent phosphorylation of $\mathrm{H} 2 \mathrm{AX}$ to form $\gamma \mathrm{H} 2 \mathrm{AX}$ [14]. We monitored DSB formation by measuring the formation of $\gamma \mathrm{H} 2 \mathrm{AX}$ following treatment of several ALL cell lines with daunorubicin. As the repair process is dynamic and may involve sequential involvement of different repair pathways we analysed DSB over a time course. Secondly, as ROS production may activate ATM, we measured ROS production following exposure of ALL cells to daunorubicin. The impact $\gamma \mathrm{H} 2 \mathrm{AX}$ and ROS levels have on ATM function and cell survival were analysed.

\section{Methods}

\section{Cell lines}

Two T-lymphoblastic leukaemia cell lines, CCRF-CEM (ATCC CCL-119) and MOLT-4 (ATCC CRL-1582), and a B-lymphoblastic leukaemia cell line, SUP-B15 (ATCC CRL-1929), were obtained from the American Type Cell Culture Collection (ATCC). Cells were stored frozen in liquid nitrogen in cryovials until use. The CCRF-CEM and MOLT-4 cells were cultured in RPMI-1640 (GibcoTM -Life Technology, NY, USA), while the SUP-B15 cells were cultured in IMDM (GibcoTM -Life Technology, NY, USA) supplemented with $10 \%$ foetal calf serum (FCS) and $5 \mathrm{mM}$ glutamine. Cells were incubated at $37^{\circ}$ $\mathrm{C}$ in aerobic atmosphere containing $5 \% \mathrm{CO}_{2}$. Cells were used before 10 passages.

\section{Daunorubicin treatment and recovery}

Daunorubicin (Sigma-Aldrich NSW, Australia) was prepared as $5 \mathrm{mM}$ stock solutions in dimethyl sulfoxide (DMSO) and stored in aliquots at $-20^{\circ} \mathrm{C}$. Cells were plated onto six well plates at a seeding density of $1 \times 10^{6}$ cells per well. Cells were treated with $10 \mu \mathrm{M}$ 
daunorubicin and incubated for $4 \mathrm{~h}$ at $37^{\circ} \mathrm{C}$ in atmosphere of $5 \% \mathrm{CO}_{2}$. Treatment media was removed by centrifugation at $200 \mathrm{~g}$ for $5 \mathrm{~min}$ and replaced with recovery media (media only) for 4,12 or $24 \mathrm{~h}$.

\section{MTT (3-(4, 5-dimethylthiazol-2-yl)-2-5 diphenyltetrazolium} bromide) assay

After treatment, cells were washed with phosphate buffer saline (PBS) and centrifuged at $4{ }^{\circ} \mathrm{C}$ at $500 \mathrm{~g}$ for 5 $\mathrm{min}$. The cells were then plated into 96 -well plate $(3 \times$ $10^{4}$ cells per well), and $0.25 \mathrm{mg} / \mathrm{ml}$ MTT (Sigma-Aldrich) was added to each well and then incubated at $37^{\circ}$ $\mathrm{C}$ for $3 \mathrm{~h}$ protected from light. Formazan crystals were solubilized by incubation in $10 \%$ DMSO at room temperature for $1 \frac{1 / 2}{2}$ hours before reading absorbance at $570 \mathrm{~nm}$ using a Flex station 3 (Molecular Devices, California, USA).

\section{ROS flow cytometry assay}

The cells were plated onto six well plates at a seeding density of $1 \times 10^{6}$ cells per well, prior to treatment and recovery. The cells were then collected and centrifuged at $400 \mathrm{~g}$ for $5 \mathrm{~min}$ before resuspending in fresh media at $1 \times 10^{5}$ cells $\mathrm{ml}^{-1}$. One $\mathrm{ml}$ of cell suspension was added to $1.5 \mathrm{ml}$ microcentrifuge tubes. As a negative control 5 $\mathrm{mM}$ of ROS inhibitor (N-acetyl-L-cysteine) (Enzo-life sciences, NY, USA) was added at least 30 min prior to induction, while $500 \mu \mathrm{M}$ pyocyanin (ROS inducer) was used as a positive control [15]. ROS detection solution (5 mM, Enzo-life sciences) was added to all tubes before incubation at $37^{\circ} \mathrm{C}$ for $30 \mathrm{~min}$ in the dark. Finally, the intensity of cell fluorescence was recorded by flow cytometry (Accuri ${ }^{\ominus}$ C6, Flow cytometery, Ann Arbor,MI, USA) using $500 \mathrm{~nm}$ excitation and $600 \mathrm{~nm}$ emission.

\section{Gamma H2AX assay}

Cells were plated in a six well plate at a seeding density of $2 \times 10^{5}$ cells per well, prior to treatment and recovery. The cells were then transferred into $1.5 \mathrm{ml}$ microcentrifuge tubes and centrifuged at $200 \mathrm{~g}$ for $5 \mathrm{~min}$. After centrifugation, cells were washed twice with ice cold Tris buffered saline (TBS, pH 7.4) to remove traces of ethanol in samples. All the samples were kept on ice during assay procedure. After washing with TBS, cells were resuspended in $500 \mu \mathrm{l}$ of ice cold TFX ( 1 x TBS, $4 \%$ FCS, $0.1 \%$ Triton-X100 made fresh for each experiment) and allowed to rehydrate for $10 \mathrm{~min}$. Cells were centrifuged again at $200 \mathrm{~g}$ and supernatant was removed. Cells were resuspended in $100 \mu \mathrm{l}$ anti-H2AX (pSer139) rabbit polyclonal IgG (ThermoFisher Scientific, Waltham, MA, USA) diluted at 1:500 in 1x TFX and incubated at room temperature for $2 \mathrm{~h}$. Cells were then washed twice with $1 \mathrm{x}$ TFX by centrifugation at $200 \mathrm{~g}$ and the supernatant discarded. Cells were resuspended in $100 \mu \mathrm{l}$ goat anti-rabbit IgG Alexa Fluor 488 conjugate antibody (ThermoFisher Scientific, USA) diluted at 1:200 in $1 \mathrm{x}$ TFX for $1 \mathrm{~h}$ at room temperature, protected from light. Cells were washed twice with $1 \mathrm{x}$ TFX and resuspended in $300 \mu \mathrm{l}$ TFX containing $5 \mu \mathrm{g} \mathrm{ml}^{-1}$ propidium iodide (Sigma Aldrich) and analysed using flow cytometry. Data was analysed using CFlow Plus software (Accuri ${ }^{\circ}$ ). Log fluorescence against cell count was plotted.

\section{Cell cycle analysis}

Fixed samples were centrifuged at $200 \mathrm{~g}$ and washed twice with ice-cold PBS. The cells then resuspended in staining solution containing $25 \mathrm{\mu g} \mathrm{ml}^{-1}$ propidium iodide and $100 \mu \mathrm{g} \mathrm{ml}^{-1}$ RNase A in cold PBS and incubated at $37^{\circ} \mathrm{C}$ for $30 \mathrm{~min}$. All the samples were analysed by using a flow cytometer (BD Accuri C6, California, USA). A total of 10,000 events were recorded for each sample.

\section{Western blotting and dot array}

After treatment with daunorubicin, cells were washed with PBS containing $1 \mathrm{mM}$ phenylmethylsulfonyl fluoride (PMSF) and centrifuged at $200 \mathrm{~g}$ for $5 \mathrm{~min}$ at $4{ }^{\circ} \mathrm{C}$. Pelleted cells were suspended with $100 \mu \mathrm{l}$ lysis buffer (Abcam, VIC, Australia), $1 \mathrm{mM}$ PMSF and $10 \mathrm{mg} \mathrm{ml}^{-1}$ aprotinin, and incubated on ice for $30 \mathrm{~min}$. Samples were then centrifuged at $15,000 \mathrm{~g}$ for $20 \mathrm{~min}$ at $4{ }^{\circ} \mathrm{C}$ and the supernatants collected. Protein concentration of each sample was determined using BSA protein assay according to the manufacturer's protocol (BIO-RAD, NSW, Australia). Each protein sample $(30 \mu \mathrm{g})$ was denatured in $5 \mu$ lithium dodecyl sulfate buffer with $200 \mathrm{mM}$ DTT at $70{ }^{\circ} \mathrm{C}$ for $10 \mathrm{~min}$ (Abcam). Samples were loaded onto $10 \%$ or $12 \%$ Tris Tricine SDS-PAGE gels (Abcam) and fractionated at $180 \mathrm{~V}$ for 30 to $70 \mathrm{~min}$ in the presence of SDS running buffer (Abcam, ab 119,195). Samples were transferred to polyvinylidene fluoride (PVDF) membrane using a mini trans-blot apparatus according to the manufacture's protocol (BIO-RAD) with $1 \mathrm{x}$ transfer buffer (Abcam). Following protein transfer, the PVDF membrane was blocked with $5 \%$ non-fat milk in TBS-T (20 $\mathrm{mM}$ Tris, $\mathrm{pH} 8.0,150 \mathrm{mM} \mathrm{NaCl}, 0.1 \%(v / \mathrm{v})$ Tween 20$)$ overnight. The PVDF membrane was washed three times with TBS-T each for $5 \mathrm{~min}$ and then incubated in either anti-SOD2 (1:1000), anti-p53 (1:1000) or anti-beta tubulin (1:5000) antibodies (Cell Signalling Technology, MA, USA) diluted in blocking buffer for $4 \mathrm{~h}$ at $4{ }^{\circ} \mathrm{C}$ with gentle agitation. The membrane was then washed with in TBS-T three times, before adding goat anti-rabbit IgG secondary antibody $(1: 10,000)$ (Cell Signalling Technology) and incubating for $4 \mathrm{~h}$ at room temperature. The PVDF was then washed with TBS-T and incubated with ChemiFast Chemiluminescence substrate (BIO-RAD). Chemiluminescence was measured in a G BOX 
(Syngene, Cambridge, UK) and the immunodensity of the bands was measured using gene tool Syngene software.

The impact of treatment on proteins involved in cell cycle arrest was explored using a commercially available human apoptosis array kit (Abcam, UK) according to the manufacturer's instructions. After treatment with daunorubicin, cells were incubated for a further $12 \mathrm{~h}$ in recovery media. Cells were removed from plates and processed according to the manufacturer's instructions Sample lysate protein concentration was determined with BioRad DC Protein Assay Kit II before blotting and immunoprobing and detection of chemiluminescence signal as described above.

\section{ATM sequencing}

RNA was isolated from $5 \times 10^{6}$ of CCRF-CEM, MOLT-4 or SUP-B15 cells using SV total RNA isolation kit (Promega, VIC, Australia). Reverse transcription was performed using the ImProm-IITM Reverse transcription system (Promega, VIC, Australia) kit. $1 \mu \mathrm{g}$ of RNA samples were mixed with $0.5 \mu \mathrm{g}$ of oligo $\mathrm{dT}, 0.5 \mu \mathrm{g}$ of random primers and nuclease-free water. The reverse transcription mix was prepared according to the Promega protocol. RNA and primers were combined with reverse transcription mixture and incubated accordingly: Annealing at $25^{\circ} \mathrm{C}$ for $5 \mathrm{~min}$; extension at $42^{\circ} \mathrm{C}$ for one hour and reverse transcriptase inactivation by incubation at $70^{\circ} \mathrm{C}$ for $15 \mathrm{~min}$. The cDNA product was stored at $20^{\circ} \mathrm{C}$ prior to use.

Primers were designed to ensure that the entire coding region of the Ataxia-telangiectasia mutated (ATM) gene was amplified (Fig. 1). Each set of primers were designed based on the wild type ATM (U82828.1, NCBI) sequence. Primers used in the experiment were designed as follows: primer length was between 18 and 25 base pairs; the primer melting temperature was calculated by A plasmid editor (ApE; http://biologylabs.utah.edu/jorgensen/wayned/ape/) software, with primers having a minimum melting temperature of $48^{\circ} \mathrm{C}$; each primer was designed to have $40-60 \%$ GC content; and palindromic sequences within primers were avoided. Primer sequences are detailed in Additional file 1: Table S1. The use of a high fidelity, low error rate DNA polymerase enzyme in the PCR reactions was essential in order to minimise errors in amplicon extension and subsequent sequencing data. $1 \mu \mathrm{g}$ cDNA samples were used as a template to generate full length high fidelity amplicons. The PCR reactions contained $0.5 \mu \mathrm{M}$ forward primer, $0.5 \mu \mathrm{M}$ reverse primer, $1 \mu \mathrm{l}$ of cDNA sample, 1x Q5 PCR high fidelity Master Mix (NEB, MA, USA), with PCR quality water making the balance to $25 \mu \mathrm{l}$. PCR conditions for the different primer pairs are defined in Additional file 1: Table S2. PCR products were cleaned in
$50 \mu \mathrm{l}$ of elution buffer using the Ultra clean PCR clean up kit (Mo Bio, CA, USA). Confirmation of PCR product size was performed by $1 \%$ agarose gel electrophoresis. Sanger sequencing was performed by the Australian Genome Research Facility in Brisbane and aligned with NCBI sequences of the ATM gene.

\section{Data analysis}

Data is presented as mean \pm standard error of the mean (SEM) and is analysed by one-way ANOVA followed by the Tukey's post-hoc test using GraphPad Prism 7 software. $P<0.05$ is considered statistically significant.

\section{Results}

\section{Effects of daunorubicin on cell viability}

Daunorubicin treatment causes many different types of toxic lesions. The MTT assay was utilised to assess changes in the number of the three ALL cell lines used in this study. Each of the cell lines displayed a different pattern of sensitivity to daunorubicin. Daunorubicin toxicity was observed in MOLT- 4 cells after $4 \mathrm{~h}$ in recovery media, the earliest time examined (Fig. 2a). The level of reduction in cell density was about $50 \%$ compared to the control after $4 \mathrm{~h}(0.56 \pm 0.05, P=0.0018)$, and remained at these levels after $12 \mathrm{~h}(0.54 \pm 0.04, P=0.0011)$ and $(0.57 \pm 0.02, P=0.014) 24 \mathrm{~h}$. CCRF-CEM cells exposed to daunorubicin (Fig. 2b) did not show significant reduction in cell density until $12 \mathrm{~h}$ in the recovery media (0.48 $\pm 0.07, P=0.0002)$ compared to the control. The significant reduction in the cell density level remained after $24 \mathrm{~h}$ recovery $(0.45 \pm 0.07, P<0.0001)$. Treatment of SUP-B15 cells (Fig. 2c) with daunorubicin resulted in a biphasic response. Initially after $4 \mathrm{~h}$ in recovery media there was a significant decrease in cell density compared to the control $(0.61 \pm 0.07, P=0.006)$. When the cells were incubated in $12 \mathrm{~h}$ recovery media, the decrease in cell density was comparable to the control $(1.08 \pm 0.07)$ and not significantly reduced at $24 \mathrm{~h}(0.76 \pm 0.06 ; P=0.945)$.

\section{Effects of daunorubicin on production of damaging reactive oxygen species}

A mechanism of action of daunorubicin is to generate reactive oxygen species (ROS), which causes DNA damage, particularly it will induce DSBs [16]. To assess the changes in ROS production over time following treatment with daunorubicin, the total ROS assay was performed (Fig. 3 and Additional file 1: Figure S1). Since daunorubicin can stimulate the production of ROS via several processes, and cells have several mechanisms for quenching toxic ROS, the differences in ROS over time reflects not only cell sensitivity, but also long term daunorubicin effectiveness. Treatment of MOLT-4 cells (Fig. 3a) with $10 \mu \mathrm{M}$ daunorubicin resulted in a 

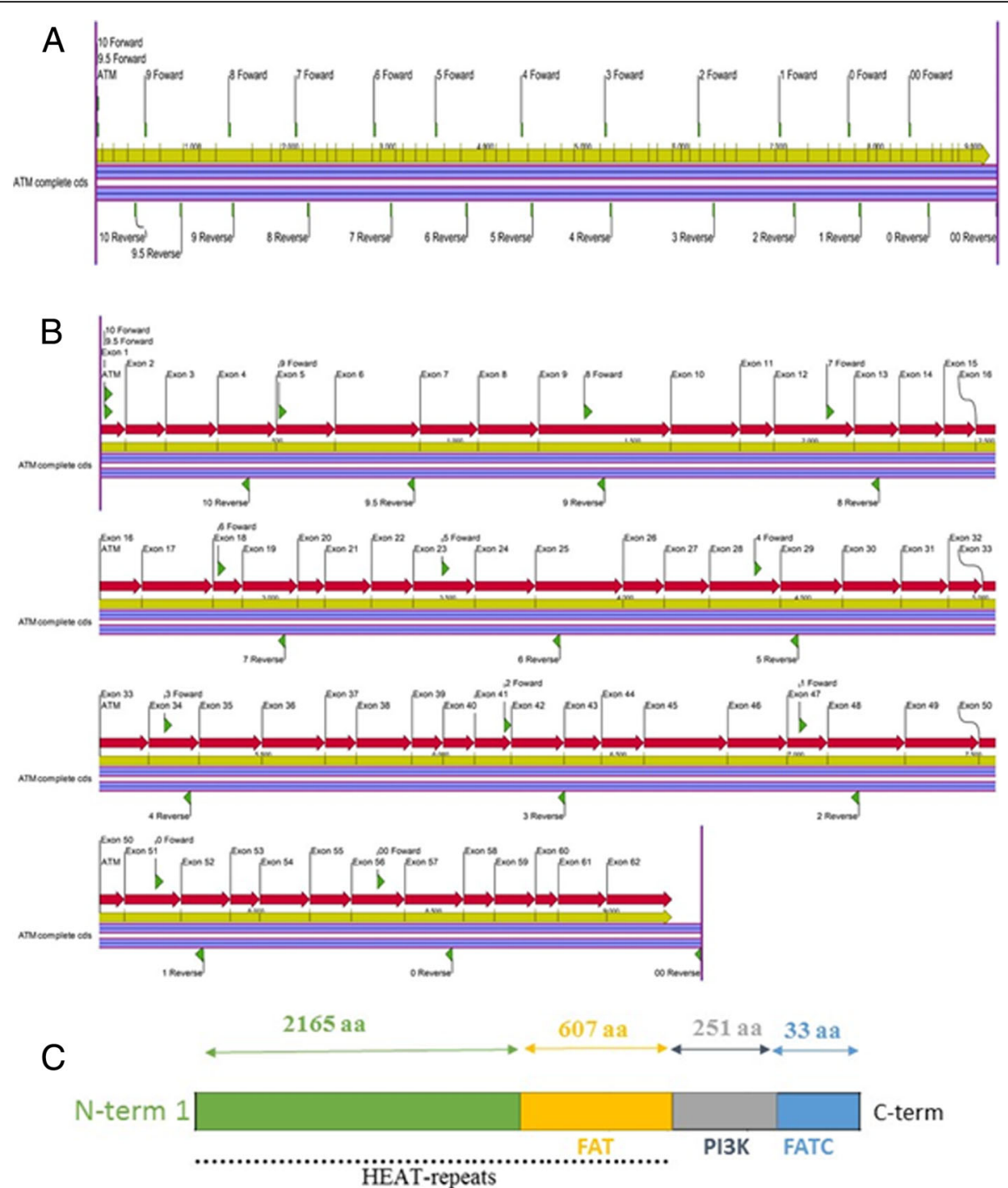

Fig. 1 Schematic structure of the ATM gene and protein. a ATM CDNA diagram and primer positions. b ATM exon diagram and primer position. The red arrows indicate exons. The yellow arrows indicate size of cDNA sequence. The green arrows indicate primer position. Both (a) and (b) diagrams were created using CLC Genomics Workbench (CA, USA). c Schematic diagram of the regions of the ATM protein kinase. The FAT domain is autophosphorylated, PI3K is the kinase domain and FATC domain interacts with Tip60 protein to activate ATM

significant increase in ROS production after $4 \mathrm{~h}$ recovery period $(10.48 \pm 0.03, P<0.0001)$ compared to the control. Increase in ROS production reached a maximum after $12 \mathrm{~h}$ recovery $(127.7 \pm 2.47, P<0.0001)$ and declined significantly after $24 \mathrm{~h}(24.90 \pm 0.40, P<0.0001)$. CCRF-CEM cells exposed to daunorubicin (Fig. 3b), displayed a similar pattern of ROS production. There was a significant increase in ROS production after $4 \mathrm{~h}$ recovery period $(47.33 \pm 0.77, P<0.0001)$ compared to the control. This increase in ROS production reached a maximum after $12 \mathrm{~h}$ recovery $(133.1 \pm 1.95, P<0.0001)$, then decreased after $24 \mathrm{~h}$ recovery $(16.0 \pm 0.21, P<0.0001)$. SUP-B15 cells (Fig. 3c) when treated with daunorubicin did not appear to be as sensitive to the production of
ROS compared to MOLT and CCRF-CEM cells. SUP-B15 cells showed a significant increase in ROS production after $4 \mathrm{~h}$ recovery period $(23.09 \pm 3.11, P<$ 0.0001) compared to the control. The amount of ROS produce was comparable following $12 \mathrm{~h}$ incubation in the recovery media $(24.75 \pm 2.79 ; P<0.0001)$ before declining after $24 \mathrm{~h}$ recovery $(9.91 \pm 1.46 P=0.0172)$.

\section{Effects of daunorubicin on DNA double strand breaks}

The lesions most detrimental to cell survival following treatment with daunorubicin, include the DSBs. The production and subsequent repair of these lesions was assessed over time by detecting $\gamma \mathrm{H} 2 \mathrm{AX}$. This also gives an indication of how effective DNA repair processes are 


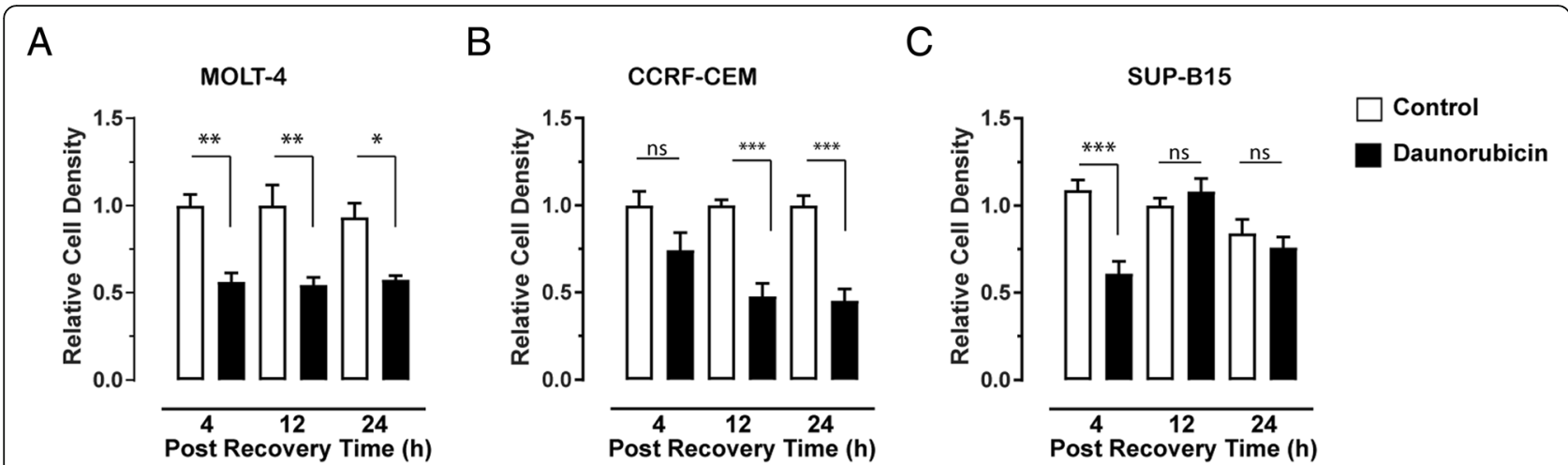

Fig. 2 Effect of daunorubicin on cell viability. Relative cell density following treatment with $10 \mu \mathrm{M}$ daunorubicin for $4 \mathrm{~h}$ and followed by 4,12 and $24 \mathrm{~h}$ (post recovery time) of recovery media for (a) MOLT-4, (b) CCRF-CEM and (c) SUP-B15 cells was determined using the MTT assay. Bars indicate mean of a total of six replicates \pm SEM, from three independent experiments. Results were normalised to the control at each time point. * $P<0.05$, ** $P<0.01$; *** $P<0.001$ one-way ANOVA followed by Tukey's post-hoc test

within T or B lymphoblast derived cells (Fig. 4 and Additional file 1: Figure S2). After $4 \mathrm{~h}$ recovery, there was no significant increase in $\gamma \mathrm{H} 2 \mathrm{AX}$ fluorescence intensity $(2.81 \pm 0.88 ; P=0.127)$ compared to the control in MOLT-4 cells (Fig. 4a). However, after $12 \mathrm{~h}$ in recovery media, there was a significant increase in $\gamma \mathrm{H} 2 \mathrm{AX}$ expression $(3.76 \pm 0.57 ; P=0.0065)$. When cells were incubated for $24 \mathrm{~h}$ in the recovery media, $\gamma \mathrm{H} 2 \mathrm{AX}$ expression decreased and was comparable to control levels $(2.35 \pm$ $0.622 ; P=0.423)$. When CCRF-CEM cells were allowed to recover for $4 \mathrm{~h}$ (Fig. $4 \mathrm{~b}$ ) following initial $4 \mathrm{~h}$ treatment with daunorubicin, there was a significant increase in the number of cells that stained positive for $\gamma \mathrm{H} 2 \mathrm{AX}$ when compared to the control $(3.91 \pm 0.54 ; P=0.0002)$. $\gamma \mathrm{H} 2 \mathrm{AX}$ expression decreased after $12 \mathrm{~h}$ in recover media, comparable to control levels $(2.37 \pm 0.38 ; P=$ 0.471). Levels of $\gamma \mathrm{H} 2 \mathrm{AX}$ remained at this level after $24 \mathrm{~h}$ recovery $(2.24 \pm 0.69 ; P=0.277)$. When SUP-B15 cells (Fig. 4c) were incubated for $4 \mathrm{~h}$ in recovery media, there was a significant increase in the percentage of cells expressing $\gamma \mathrm{H} 2 \mathrm{AX}$ when incubated in the recovery media for $4 \mathrm{~h}(2.45 \pm 0.45 ; P=0.0148)$. Expression levels remained elevated after $12 \mathrm{~h}(2.59 \pm 0.23 ; P=0.0024)$ and $24 \mathrm{~h}$ incubation in the recovery media $(3.13 \pm 0.43 ; P<$ 0.0001).

\section{Effects of daunorubicin on cell cycle progression}

Following the toxic effects of daunorubicin, the cell should respond by initiating cell cycle arrest to allow DNA repair processes to occur. Analysis of cell cycle stages can be assessed using propidium iodide staining, to determine the impact of daunorubicin on cell cycle progression or arrest at different times after treatment (Fig. 5). As shown in Fig. 4a, cell cycle profiles for MOLT-4 after $4 \mathrm{~h}$ in recovery media (15.5:42:42.5; G1:S:G2/M) there was an increase in the proportion of cells in G2/M phase of the cell cycle when compared to control (48:41:11), with a subsequent decrease in G1 phases. The proportion of cells continued to accumulate in the $\mathrm{G} 2 / \mathrm{M}$ phase after $12 \mathrm{~h}$ recovery $(10.5: 23.5: 66)$


Fig. 3 Total Reactive oxygen species (ROS) induced by daunorubicin. MOLT-4 (a), CCRF-CEM (b) and SUP-B15 (c) cells exposed to $4 \mathrm{~h}$ treatment with $10 \mu \mathrm{M}$ daunorubicin, followed by 4,12 and $24 \mathrm{~h}$ (post recovery period) in recovery media. Graph indicates mean of total of six replicates \pm SEM, from three independent experiments. Results were normalised to the control at each time point. ${ }^{*} P<0.05$, $^{* *} P<0.01 ;{ }^{* * *} P<0.001$; ${ }^{* * * *} P$ $<0.0001$ one-way ANOVA followed by Tukey's post-hoc test 


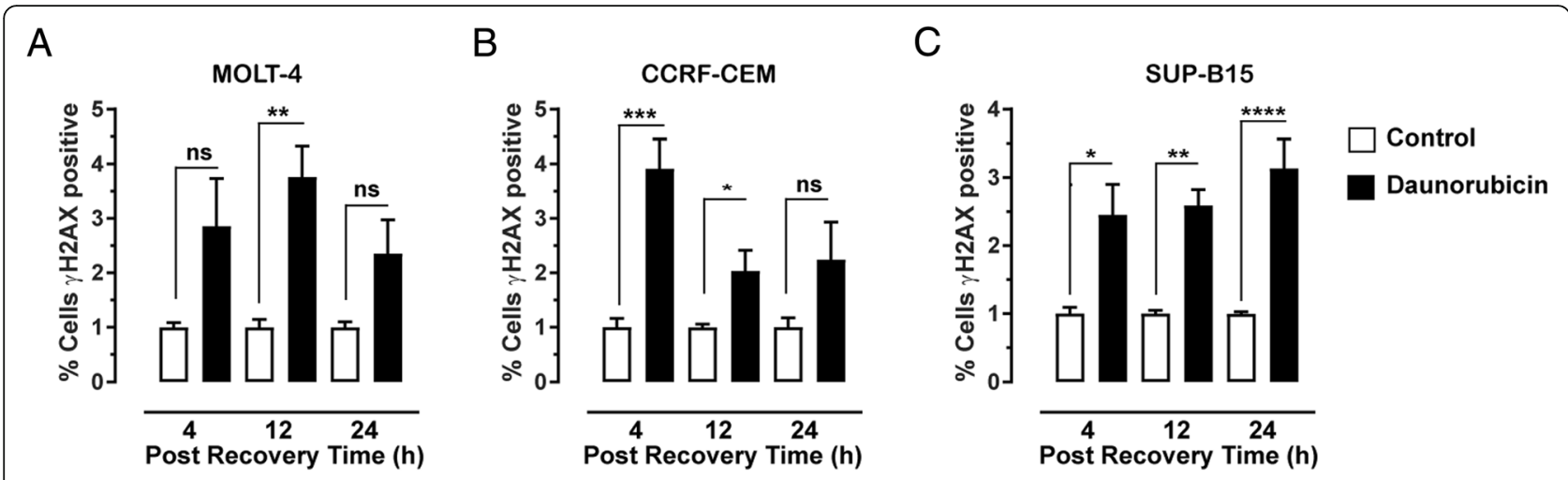

Fig. 4 Effect of daunorubicin on DSB. Measurement of DSB by YH2AX fluorescence for MOLT-4 (a), CCRF-CEM (b) and SUP-B15 (c) cells following $4 \mathrm{~h}$ treatment with $10 \mu \mathrm{M}$ daunorubicin, followed by 4, 12 and $24 \mathrm{~h}$ (post recovery period) in recovery media. Median intensities from (flow cytometry histograms of the raw data) were used to plot the bar diagram. Graph indicates mean of total of six replicates \pm SEM, from three independent experiments. Results were normalised to the control at each time point. ${ }^{*} P<0.05,{ }^{* *} P<0.01$; ${ }^{* *} P<0.001$ one-way ANOVA followed by Tukey's post-hoc test

with further reduction in G1 phase, but after $12 \mathrm{~h}$ there was also a reduction in cells in S phase. After $24 \mathrm{~h}$ recovery time, the cell cycle profile returned to normal levels (49:32.5:18.5). Similarly, the cell cycle profiles for CCRF-CEM cells (Fig. 5b) showed a dramatic increase in the proportional of cells in G2/M phases of cell cycle when compared to control. The proportion of cells in the G2/M phase continued to increase after $12 \mathrm{~h}$ recovery. The accumulation of cells in the G2/M phase resulted in a reduction of cells in the G1 and S phase of cell cycle. After $24 \mathrm{~h}$ recovery time, the cell cycle profile returned to normal levels. In contrast, the cell cycle profiles for SUP-B15 cells (Fig. 5c) showed an increase in the proportion of cells in G1 phase and G2/M phase of cell cycle when compared to control after $4 \mathrm{~h}$ of incubation in recovery media. The proportion of cells in G1 phase was further increased when the cells were incubated after $12 \mathrm{~h}$, further increasing after $24 \mathrm{~h}$ recovery. Cells accumulating in the G1 phase resulted in a reduction of cells in the G2/M and S phase of cell cycle.

\section{Expression of $\mathrm{p} 53$ and SOD2}

DSB activates ATM [17] and the differences in cell cycle recovery may be due to mutations in ATM. To determine if functional mutations in ATM were affecting how cells handle chemotherapy treatment, the full ATM sequence in T-lymphoblast derived CCRF-CEM and MOLT-4 cells and B-lymphoblast derived SUP-B15 cells were explored through Sanger sequencing. The coding region was fully amplified using a selection of primer pairs (Fig. 1) and the products were sequenced. This was

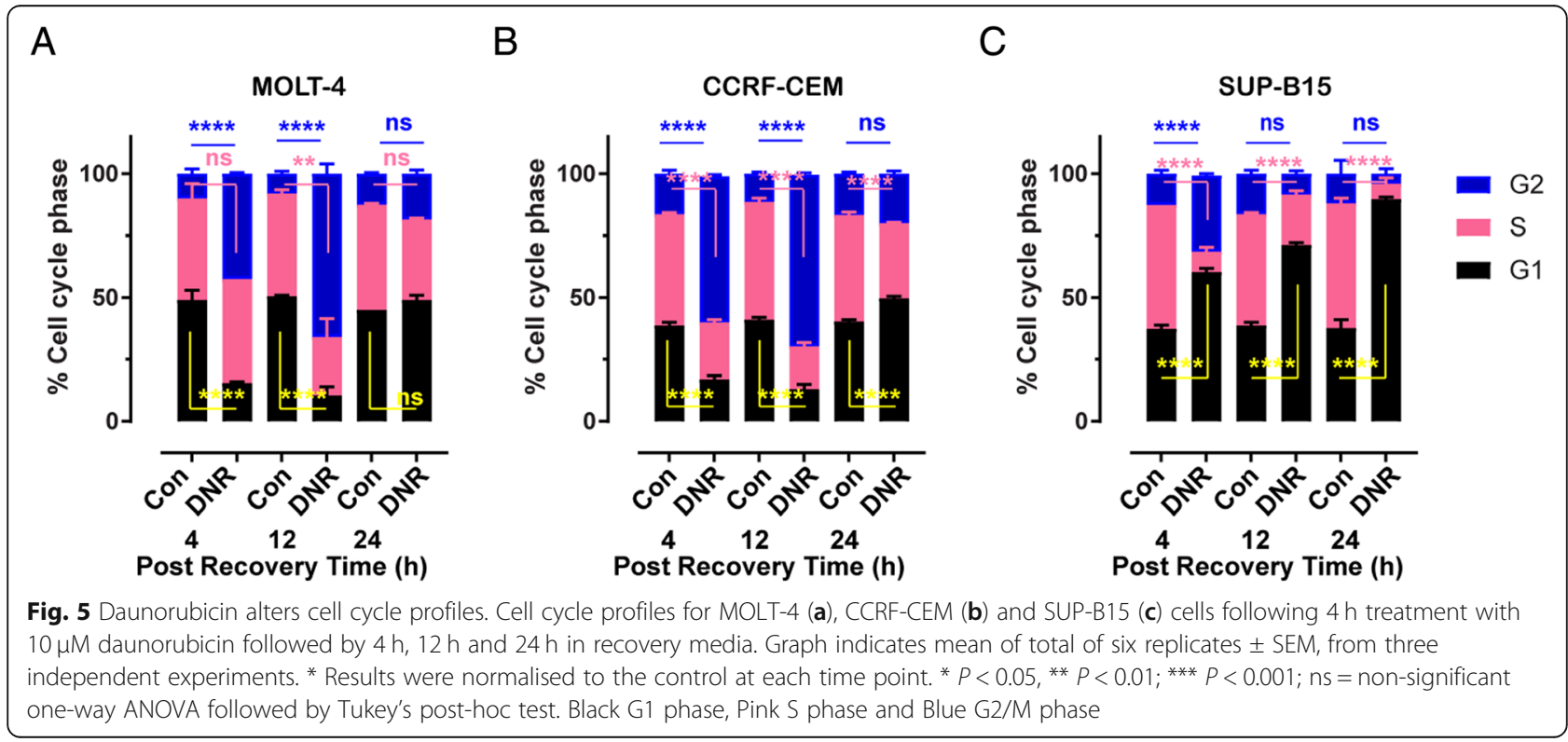


done for each of the cell lines and no mutations found in the full ATM coding region.

Following detection of DSB, activation of p53 initiates several downstream processes, including activation of SOD2 to quench ROS, and maintain cell survival. Analysis of p53 in the three ALL cell lines following treatment, indicated a lack of p53 phosphorylation at Ser15 in SUP-B15 cells. Whereas the phosphorylation of p53 in both CCRF-CEM and MOLT4 cell lines was observed (Fig. 6a). SOD2 was unchanged in both MOLT-4 and CCRF-CEM and increased in SUP-B15 cells (Fig. 6b), although the later effect could be due to reduced ROS production seen in SUP-B15 cells (Fig. 3c). This dysfunction of p53 would also have an impact on cell cycle regulators, including p21 and p27, which are both down regulated in SUP-B15 cells following treatment with daunorubicin (Table 1).

\section{Discussion}

Assessment of the impact of daunorubicin on the selected leukaemic cell lines revealed very different cellular responses and sensitivity to daunorubicin. The ALL cell lines, MOLT-4 and CCRF-CEM which are derived from acute T-lymphoblastic leukemia, displayed a cytotoxic response, with DNA-DSB and cell cycle arrest to allow subsequent DNA repair to occur. However, the ALL cell line, SUP-B15 derived from an acute B-lymphoblastic leukaemia, displayed a different pattern of response. SUP-B15 cells showed no signs of DNA-DSB repair, and cells accumulating in $\mathrm{G} 1$ phase, as opposed to G2/M in the other cell lines.

All cell lines in this study responded to the cytotoxic effects of daunorubicin with a reduction in cell number which supports previous studies [13, 18, 19]. MOLT-4 cells appeared to be the most sensitive, with a persistent decrease in cell number observed as early as $4 \mathrm{~h}$ post treatment. CCRF-CEM cells did not succumb to the cytotoxicity until $12 \mathrm{~h}$ post treatment, levels at this time were comparable to MOLT-4, and remained at this level for the duration of the study time. However, SUP-B15 cells displayed a different pattern of response and appeared less sensitive to the drug especially after 12 and $24 \mathrm{~h}$. The concentration of daunorubicin $(10 \mu \mathrm{M})$ used in this study was shown to be effective in Jurkat $\mathrm{T}$ lymphoma and HL-60 promyelocytic leukaemia cell line [20] and sarcoplasmic reticulum cardiac cells [21].

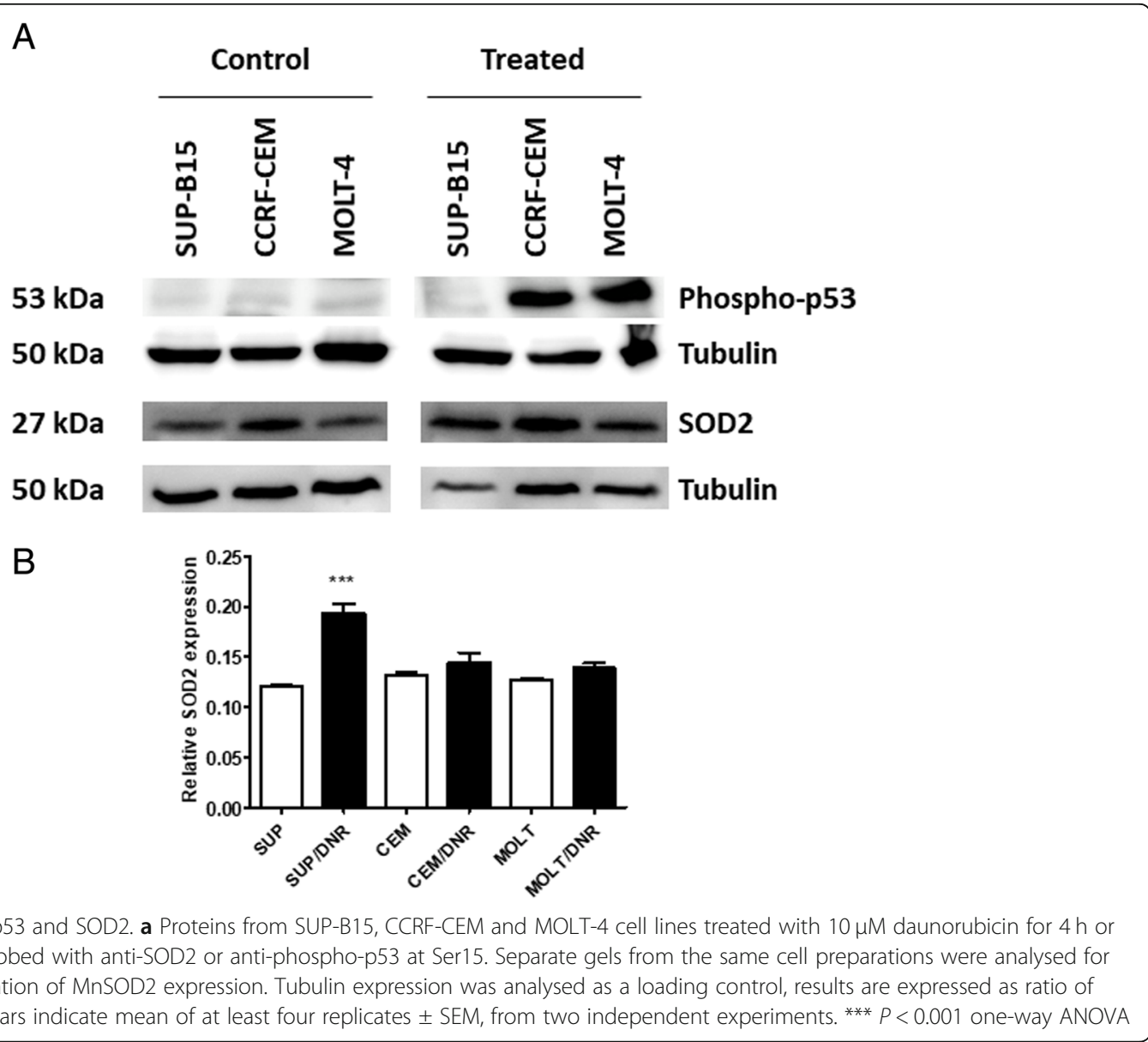


Table 1 Summary of results from the apoptosis array showing the effect daunorubicin on p53, p21 and p27 in MOL-4, CCRF CEM and SUP-B15 cell lines

\begin{tabular}{|c|c|c|c|c|c|c|}
\hline \multirow[t]{2}{*}{ Protein } & \multicolumn{2}{|l|}{ MOLT-4 } & \multicolumn{2}{|c|}{ CCRF-CEM } & \multicolumn{2}{|l|}{ SUP-B15 } \\
\hline & DNR 4h & Recovery Media $12 \mathrm{~h}$ & DNR 4h & Recovery Media $12 \mathrm{~h}$ & DNR 4h & Recovery Media $12 \mathrm{~h}$ \\
\hline $\mathrm{p} 53$ & $\uparrow$ & - & $\uparrow$ & - & $\downarrow$ & $\downarrow$ \\
\hline p21 & $\uparrow$ & - & $\uparrow$ & - & $\downarrow$ & $\downarrow$ \\
\hline p27 & $\uparrow$ & - & $\uparrow$ & $\uparrow$ & $\downarrow$ & - \\
\hline
\end{tabular}

The effectiveness of a chemotherapeutic agent is dependent on several factors; concentration, exposure time, doubling time of the cell line, state of DNA Damage Response (DDR) mechanisms and type of damage induced. Most of these characteristics are primarily determined by the genetics of the cell line. Many chemotherapeutic agents, such as daunorubicin, elicit their damage by disrupting or targeting the replication of DNA during the $\mathrm{S}$ phase of the cell cycle. Cells that complete more cell cycles (have shorter doubling times) are therefore more vulnerable to the chemotherapeutic agent when compared to a cell line that completes fewer cell cycles (longer doubling time). The CCRF-CEM cells have a doubling time ranging from 20 to $30 \mathrm{~h}$ [22], therefore the CCRF-CEM cells would have at least one cell cycle to identify and repair the damage induced by the chemotherapeutic tested. MOLT- 4 cells have a doubling time of approximately $22-24 \mathrm{~h}$ [23-25]. So again, MOLT-4 would have one cell cycle to identify and repair the damage induced by the chemotherapeutic agents. SUP-B15 cells would have only entered the second cell cycle during the observed treatment time as the doubling time of SUP-B15 cells is approximately $46 \mathrm{~h}$, with reports ranging from 35 to $60 \mathrm{~h}[26,27]$. This may explain the observed results as half of SUP-B15 cells have been affected, while MOLT- 4 and CCRF-CEM the majority of cells have been damaged.

Free radical formation and oxidative stress play an important role in the cytotoxicity of daunorubicin as ROS may serve as an intracellular signal of apoptotic events [28]. Daunorubicin induced ROS in the three leukaemic cells lines with variations over the time period. The T-lymphoblast cell lines, CCRF-CEM and MOLT-4 produced ROS at high levels from 4 to $12 \mathrm{~h}$ before declining sharply over the next $12 \mathrm{~h}$. However, the B lymphoblast SUP-B15 cells consistently expressed significant but relatively lower ROS levels throughout the experimental period. Daunorubicin induces cytotoxicity in the cells by the generation of ROS and enhanced G2/M phase cell cycle [29]. Increases in the level of ROS is regulated by several signal networks, antioxidants such as superoxide dismutase (SOD2), catalase (CAT) and glutathione peroxidase 1 (GPx) play a central role [30]. The overall effect of the antioxidant system depends on the intracellular balance between these and other antioxidant enzymes rather than a single component. In the antioxidant enzyme system, SOD2 catalyses the dismutation of superoxide radicals to $\mathrm{H}_{2} \mathrm{O}_{2}$. p53 is an essential tumour suppressor gene, that also regulates SOD2 (or MnSOD) gene expression [31]. Thus in SUP-B15 cells where p53 is not activated, the antioxidant effects of SOD2 will not modulate ROS levels during the daunorubicin treatment [32]. p53-dependent up-regulation of SOD2 and glutathione peroxidase 1 (GPx) is important in human lymphoblasts [33]. However, p53-mediated production of ROS can be cell type and species dependent [33].

Although ATM was expressed in all three cell lines and contained no mutations in the coding regions, p53 was phosphorylated in MOLT-4 and CCRF-CEM but not in SUP-B15 after daunorubicin treatment. Hence, p53 in SUP-B15 is more likely to be mutated. Leukaemia cells often possess mutations in p53 gene [34].

To determine the impact of daunorubicin on the DSBs in the selected ALL cell lines, and the subsequent repair, we analysed the $\gamma \mathrm{H} 2 \mathrm{AX}$ levels. The histone H2AX plays a key role in DNA-DSB repair by rapidly phosphorylating serine residues to form $\gamma \mathrm{H} 2 \mathrm{AX}$ foci near the DSBs [35]. Treatment of all cell lines with daunorubicin resulted in an increase in $\gamma \mathrm{H} 2 \mathrm{AX}$ staining within $4 \mathrm{~h}$ indicating this is an appropriate treatment time and supporting previous studies that show daunorubicin causes DSBs $[36,37]$. To follow the dynamics of DSB repair, cells were allowed to recover over $24 \mathrm{~h}$ when there were still significant levels of DSBs detected. This indicates that even though repair was occurring, not all DBSs induced were repaired during this time. Notably, SUP-B15 cell line showed more pronounced DSBs at 12 and $24 \mathrm{~h}$ recovery time compared to MOLT-4 and CCRF-CEM cell lines, suggesting that different DDR mechanisms or pathways were involved. DSB repair in CCRF-CEM cells appeared the most robust, with repair occurring after $4 \mathrm{~h}$ in recovery and total repair after 24 h. MOLT- 4 showed that the DSB repair took place after $12 \mathrm{~h}$ in recovery. This indicates that the $24 \mathrm{~h}$ recovery time is enough for some repair of daunorubicin induced DSB in MOLT-4 and CCRF-CEM cells. On the other hand, even after $24 \mathrm{~h}$ recovery, the level of DSBs in SUP-B15 cells was significantly higher indicating incomplete DSB repair. Most cells have an intrinsic repair 
process in response to any DNA damage, including those induced by daunorubicin. The effectiveness of the DDR will be cell line dependent, with some cell lines having mutations in the key signalling intermediary p53 [38, 39] as seen in SUP-B15 in this study. Dependent on the DNA damage that has been induced, single stranded breaks or DSB, different DDR pathways will be signalled. Daunorubicin induced DNA-DSB primarily utilise the HR and NHEJ repair pathways [40]. Mutations to important elements of the HR or NHEJ, can compromise the DDR mechanisms, resulting in less damage being identified and appropriate cellular responses stimulated. Increased expression of such enzymes leads to increased repair following exposure to chemotherapies inducing DSB, including daunorubicin, and this is a key mechanism in the ever growing problem of chemoresistance to therapy [41, 42]. The difference in potency of the chemotherapy in the three cell lines could be due to the difference in molecular profiles between the three cell lines, and one pertinent example is p53 status.

Along with reduction of detectable $\gamma \mathrm{H} 2 \mathrm{AX}$, and thus DSBs, during the recovery time, DNA-PK, ATM and ATR also initiate cell cycle arrest. Exposing SUP-B15 cells to daunorubicin caused a progressive accumulation of cells in G1 phase while daunorubicin treatment of MOLT-4 and CCRF-CEM cells caused a profound accumulation of cells in $\mathrm{G} 2 / \mathrm{M}$ phase, with a progressive reduction of cells in $\mathrm{G} 1$ and S phase of the cell cycle. However, after $24 \mathrm{~h}$ recovery the cell cycle profile of MOLT-4 and CCRF-CEM cells was comparable to the control, suggesting the impact on cell cycle was no longer expressed. This is consistent with the previous observation in HL-60 cells (myeloid leukaemic cell line) where daunorubicin caused a marked G2/M accumulation after $24 \mathrm{~h}$ of exposure to the drug [43]. The profound accumulation in G2/M has also been observed in CCRF-CEM cells treated with the anthracycline doxorubicin [44]. Doxorubicin also induced profound G2/M arrest in HCT-116 human colon carcinoma cells and was accompanied by activation of p53 and induction of p21 mRNA and protein expression [45].

The cell line dependent variations in various enzyme expression levels, particularly p53, p27 and p21, could be a factor in the differences in the degree of cell cycle arrest and subsequent DSB repair. In many cancer cells, loss of p53 is thought to be a predictor of failure to respond to chemotherapy and radiotherapy [46]. Treatment of MOLT-4 and CCRF-CEM with daunorubicin resulted in increased the level of p53, p27 and p21, corresponding with increased levels of DNA DSBs and cell cycle arrest. In contrast, SUP-B15 cells showed decreases in the levels of p53, p27 and p21. Several studies have provided compelling evidence relating the mutations in p53 with chemoresistance to various cytotoxic drugs [38, 47-50].
Following DNA damage, phosphorylation of p53 at Ser15 by ATM or other kinases inhibits the binding of MDM2 to p53 and this leads to increased activity of p53. Anthracycline mediated cell cycle arrest may take place at G1 or G2 checkpoints and this can be mediated through the multifunctional transcription factor p53 [51, 52]. p53 induces p 21 (CDK inhibitor) expression and therefore, inactivation of p53 will also result in decreasing levels of p21 [53]. p27 is also a member of CIP/KIP and controls cell progression from $\mathrm{G} 1$ to $\mathrm{S}$ phase by mediating G1 arrest through inhibiting cyclin/CDK complex activities [54]. Normally, p53 may boost chemosensitivity through enhancing p21-mediated growth arrest and DNA repair [55]. p53 has two functional roles, it can induce cell cycle arrest, through the transactivation of the p21 or induction of apoptosis [56]. Additionally, DSBs induced by chemotherapy activate ATM to in turn stimulate breast cancer type 1 susceptibility protein (BRCA1), together with various other associated protein complexes such as BRCA2 and Rad51 to initiate HR DNA repair processes [57]. The contribution of BRCA1 and other proteins needs to be explored in these cells lines as the absence of BRCA1 or BRCA2 can lead to an inability to repair DSB $[58,59]$.

\section{Conclusions}

In summary, the study provides additional insight into the mechanism of action of daunorubicin on DNA DSB formation, DNA repair and the cell cycle arrest in acute lymphoblastic leukaemia cell lines. The delay in DSB repair and lower sensitivity to daunorubicin in the $B$ lymphoblastic SUP-B15 cells is likely to involve loss of p53 function amongst other factors. These factors may contribute in inhibiting or affecting DNA repair pathways. As p53, p21 and p27 phospho-kinase proteins play essential roles in tumour progression and clinical outcomes in acute lymphoblastic leukaemia, the presence and activity regulatory proteins should be taken into consideration in devising personalized treatment regimens.

\section{Additional file}

\begin{abstract}
Additional file 1: Figure S1. Examples of histograms used for the ROS assay. Illustrative histograms obtained from (A) MOLT-4, (B) CCRF-CEM, and (C) SUP-B15 cell lines. Figure S2. Examples of histograms used for the gamma $H 2 A X$ assay. Illustrative histograms obtained from (A) MOLT4, (B) CCRF-CEM, and (C) SUP-B15 cell lines. Table S1. Primers used to amplify the ATM CDNA. Table S2. PCR conditions for the different primer sets to amplify ATM. (PDF $286 \mathrm{~kb}$ )
\end{abstract}

\section{Abbreviations}

ALL: Acute lymphoblastic leukaemia; ATM: Ataxia-telangiectasia mutated; BRCA1: Breast cancer type 1 susceptibility protein; DSB: DNA double strand breaks; FCS: Foetal calf serum; HR: Homologous recombination; MTT: 3-(4, 5dimethylthiazol-2-yl)-2-5 diphenyltetrazolium bromide; NHEJ: Nonhomologous end joining; p53: Protein 53; PBS: Phosphate buffer saline; PMSF: Phenylmethylsulfonyl fluoride; PVDF: Polyvinylidene fluoride; 
ROS: Reactive oxygen species; SOD2: Superoxide dismutase; TBS: Tris buffered saline; $y \mathrm{H} 2 \mathrm{AX}$ : Gamma histone H2AX

\section{Acknowledgements}

Not applicable

\section{Funding}

The authors would like to thank La Trobe Institute of Molecular Sciences (LIMS) and La Trobe University Research Focus Areas for supporting the research costs associated with the experiments. Hussain Al-Aamri would like to thank the Ministry of Higher Education, Government of Oman for providing a Postgraduate Research Scholarship.

\section{Availability of data and materials}

All data generated or analysed during this study are included in this article and its Additional file 1.

\section{Authors' contributions}

$\mathrm{CB}$, TMA and HAA conceived the project. HAA designed and performed the cell biology experiments; HK designed, performed and analysed the ATM sequencing experiments. CB and JT were involved in the design and analysis of the cell biology and sequencing experiments. HA-A, TMA and HRI analysed cell biology experiments and co-wrote the paper. HAA, HK, JT, TMA and $\mathrm{HRI}$ were involved in revising the manuscript. All authors have read and approved the manuscript.

\section{Ethics approval and consent to participate}

Not applicable

\section{Consent for publication}

Not applicable

\section{Competing interests}

The authors declare that they have no competing interests.

\section{Publisher's Note}

Springer Nature remains neutral with regard to jurisdictional claims in published maps and institutional affiliations.

\section{Received: 25 October 2018 Accepted: 18 February 2019}

\section{Published online: 27 February 2019}

\section{References}

1. Weiss RB. The anthracyclines: will we ever find a better doxorubicin? Semin Oncol. 1992:19:670-86.

2. Agudelo D, Bourassa P, Bérubé G, Tajmir-Riahi H-A. Intercalation of antitumor drug doxorubicin and its analogue by DNA duplex: structura features and biological implications. Int J Biol Macromol. 2014;66:144-50.

3. Nelson EM, Tewey KM, Liu LF. Mechanism of antitumor drug action: poisoning of mammalian DNA topoisomerase II on DNA by 4'-(9acridinylamino)-methanesulfon-m-anisidide. Proc Natl Acad Sci U S A. 1984; 81:1361-5.

4. Gewirtz D. A critical evaluation of the mechanisms of action proposed for the antitumor effects of the anthracycline antibiotics adriamycin and daunorubicin. Biochemical pharmacology, 1999. 57(7): p. 727-741. A critical evaluation of the mechanisms of action proposed for the antitumor effects of the anthracycline antibiotics adriamycin and daunorubicin. Biochem Pharmacol. 1999:57:727-41.

5. Stiff T, Walker SA, Cerosaletti K, Goodarzi AA, Petermann E, Concannon P, O'Driscoll M, Jeggo PA. ATR-dependent phosphorylation and activation of ATM in response to UV treatment or replication fork stalling. EMBO J. 2006; 25:5775-82

6. Tanaka T, Halicka HD, Huang X, Traganos F, Darzynkiewicz Z. Constitutive histone H2AX phosphorylation and ATM activation, the reporters of DNA damage by endogenous oxidants. Cell Cycle. 2006:5:1940-5.

7. Rogakou EP, Boon C, Redon C, Bonner WM. Megabase chromatin domains involved in DNA double-strand breaks in vivo. J Cell Biol. 1999:146:905-16.

8. Evison BJ, Chiu F, Pezzoni G, Phillips DR, Cutts SM. Formaldehyde-activated pixantrone is a monofunctional DNA alkylator that binds selectively to $\mathrm{CpG}$ and CpA doublets. Mol Pharmacol. 2008;74:184-94.
9. Armata HL, Golebiowski D, Jung DY, Ko HJ, Kim JK, Sluss HK. Requirement of the ATM/p53 tumor suppressor pathway for glucose homeostasis. Mol Cell Biol. 2010;30:5787-94.

10. Vogelstein B, Lane D, Levine AJ. Surfing the p53 network. Nature. 2000;408: 307-10.

11. Bunz F, Dutriaux A, Lengauer C, Waldman T, Zhou S, Brown J, Sedivy J, Kinzler K, Vogelstein B. Requirement for p53 and p21 to sustain G2 arrest after DNA damage. Science. 1998;282:1497-501.

12. Guo Z, Deshpande R, Paull TT. ATM activation in the presence of oxidative stress. Cell Cycle. 2010;9:4805-11.

13. Stojak M, Mazur L, Opydo-Chanek M, Łukawska M, Oszczapowicz I. In vitro induction of apoptosis and necrosis by new derivatives of daunorubicin. Anticancer Res. 2013:33:4439-43.

14. Cremona C, Behrens A. ATM signalling and cancer. Oncogene. 2014;33:3351.

15. Eruslanov E, Kusmartsev S. Identification of ROS using oxidized DCFDA and flow-cytometry. Meth Mol Biol. 2010;594:57-72.

16. Liu Y-W, Sakaeda T, Takara K, Nakamura T, Ohmoto N, Komoto C, Kobayashi $H$, Yagami T, Okamura N, Okumura K. Effects of reactive oxygen species on cell proliferation and death in HeLa cells and its MDR1-overexpressing derivative cell line. Biol Pharm Bull. 2003;26:278-81.

17. Maréchal A, Zou L. DNA damage sensing by the ATM and ATR kinases. Cold Springs Harbor Perspect Biol. 2013;5:a012716.

18. Stojak M, Mazur L, Opydo-Chanek M, Łukawska M, Oszczapowicz I. Effects of structural modifications of daunorubicin on in vitro antileukemic activity. Anticancer Res. 2012;32:5271-7.

19. Wasowska-Lukawska M, Wietrzyk J, Opolski A, Oszczapowicz J, Oszczapowicz I. Biological properties of new derivatives of daunorubicin. In Vivo. 2007;21:413-6.

20. Boland MP, Foster SJ, O'Neill LA. Daunorubicin activates NFKB and induces KB-dependent gene expression in HL-60 promyelocytic and Jurkat T lymphoma cells. J Biol Chem. 1997;272:12952-60.

21. Hanna AD, Janczura M, Cho E, Dulhunty AF, Beard NA. Multiple actions of the anthracycline daunorubicin on cardiac ryanodine receptors. Mol Pharmacol. 2011:80:538-49.

22. Shorey LE, Hagman AM, Williams DE, Ho E, Dashwood RH, Benninghoff AD. 3, 3'-Diindolylmethane induces G1 arrest and apoptosis in human acute Tcell lymphoblastic leukemia cells. PLoS One. 2012;7:e34975.

23. Min J, Wang X, Tong Y, Li X, Tao D, Hu J, Xie D, Gong J. Expression of cyclins in high-density cultured cells and in vivo tumor cells. Cytometry Part A. 2012;81:874-82

24. Oin J, Tao D, Duan R, Leng Y, Shen M, Zhou H, Feng Y, Gao C, Yu Y, Li QQ Cytokinetic analysis of cell cycle and sub-phases in MOLT-4 cells by cyclin E + a/DNA multiparameter flow cytometry. Oncol Rep. 2002;9:1041-5.

25. Traganos F, Ardelt B, Halko N, Bruno S, Darzynkiewicz Z. Effects of genistein on the growth and cell cycle progression of normal human lymphocytes and human leukemic MOLT-4 and HL-60 cells. Cancer Res. 1992:52:6200-8

26. Alsadeq A, Strube S, Krause S, Carlet M, Jeremias I, Vokuhl C, Loges S, Aguirre-Ghiso J, Trauzold A, Cario G. Effects of p38a/ $\beta$ inhibition on acute lymphoblastic leukemia proliferation and survival in vivo. Leukemia. 2015;29: 2307

27. Naumovski L, Morgan R, Hecht F, Link MP, Glader BE, Smith SD. Philadelphia chromosome-positive acute lymphoblastic leukemia cell lines without classical breakpoint cluster region rearrangement. Cancer Res. 1988;48:2876-9.

28. Heaton RK, Franklin DR, Ellis RJ, McCutchan JA, Letendre SL, LeBlanc S, Corkran SH, Duarte NA, Clifford DB, Woods SP. HIV-associated neurocognitive disorders before and during the era of combination antiretroviral therapy: differences in rates, nature, and predictors. J NeuroOncol. 2011;17:3-16

29. Stojak M, Łukawska M, Oszczapowicz I, Opydo-Chanek M, Mazur L. Cell-cycle disturbance and induction of programmed death by new formamidine analogs of daunorubicin. Anticancer Res. 2014;34:7151-8.

30. Amstad P, Moret R, Cerutti P. Glutathione peroxidase compensates for the hypersensitivity of $\mathrm{Cu}, \mathrm{Zn}$-superoxide dismutase overproducers to oxidant stress. J Biol Chem. 1994;269:1606-9.

31. Liu B, Chen Y, Clair DKS. ROS and p53: a versatile partnership. Free Rad Biol Med. 2008;44:1529-35.

32. Candas D, LI J J MnSOD in oxidative stress response-potential regulation via mitochondrial protein influx. Antioxid Redox Signal. 2014;20:1599-617.

33. Hussain SP, Amstad P, He P, Robles A, Lupold S, Kaneko I, Ichimiya M, Sengupta S, Mechanic L, Okamura S. p53-induced up-regulation of MnSOD 
and GPx but not catalase increases oxidative stress and apoptosis. Cancer Res. 2004;64:2350-6.

34. Zenz T, Häbe S, Denzel T, Mohr J, Winkler D, Bühler A, Sarno A, Groner S, Mertens D, Busch R. Detailed analysis of p53 pathway defects in fludarabine-refractory chronic lymphocytic leukemia (CLL): dissecting the contribution of 17p deletion, TP53 mutation, p53-p21 dysfunction, and miR34a in a prospective clinical trial. Blood. 2009;114:2589-97.

35. Redon C, Pilch D, Rogakou E, Sedelnikova O, Newrock K, Bonner W. Histone H2a variants H2AX and H2AZ. Curr Opin Genet Dev. 2002;12:162-9.

36. Ciesielska E, Studzian K, Wąsowska M, Oszczapowicz I, Szmigiero L. Cytotoxicity, cellular uptake and DNA damage by daunorubicin and its new analogues with modified daunosamine moiety. Cell Biol Toxicol. 2005;21: 139-47.

37. Lotfi K, Zackrisson A-L, Peterson C. Comparison of idarubicin and daunorubicin regarding intracellular uptake, induction of apoptosis, and resistance. Cancer Lett. 2002;178:141-9.

38. Oren M, Rotter V. Mutant p53 gain-of-function in cancer. Cold Springs Harbor Perspect Biol. 2002;2:a001107.

39. Rivlin N, Brosh R, Oren M, Rotter V. Mutations in the p53 tumor suppressor gene: important milestones at the various steps of tumorigenesis. Genes Cancer. 2011;2:466-74.

40. Huhn D, Bolck HA, Sartori AA. Targeting DNA double-strand break signalling and repair: recent advances in cancer therapy. Swiss Med Week. 2013;143: w13837.

41. Lee JT, Steelman LS, McCubrey JA. Phosphatidylinositol 3'-kinase activation leads to multidrug resistance protein-1 expression and subsequent chemoresistance in advanced prostate cancer cells. Cancer Res. 2004;64: 8397-404.

42. Stronach EA, Alfraidi A, Rama N, Datler C, Studd JB, Agarwal R, Guney TG, Gourley C, Hennessy BT, Mills GB. HDAC4-regulated STAT1 activation mediates platinum resistance in ovarian cancer. Cancer Res. 2011;71:441222.

43. Chikayama S, Kimura S, Kobayashi Y, Abe T, Maekawa T, Kondo M. Effects of daunorubicin on cell growth, cell cycle and induction of apoptosis in HL-60 cells. Haematologia. 1998;29:115-21.

44. Savatier J, Rharass T, Canal C, Gbankoto A, Vigo J, Salmon J-M, Ribou A-C. Adriamycin dose and time effects on cell cycle, cell death, and reactive oxygen species generation in leukaemia cells. Leukemia Res. 2012;36:791-8.

45. Lüpertz R, Wätjen W, Kahl R, Chovolou Y. Dose-and time-dependent effects of doxorubicin on cytotoxicity, cell cycle and apoptotic cell death in human colon cancer cells. Toxicology. 2010;271:115-21.

46. Weller M. Predicting response to cancer chemotherapy: the role of p53. Cell Tissue Res. 1998;292:435-45.

47. Bunz F, Hwang PM, Torrance C, Waldman T, Zhang Y, Dillehay L, Williams J, Lengauer C, Kinzler KW, Vogelstein B. Disruption of p53 in human cancer cells alters the responses to therapeutic agents. J Clin Invest. 1999;104:2639.

48. Lee JM, Bernstein A. p53 mutations increase resistance to ionizing radiation. Proc Natl Acad Sci U S A. 1993;90:5742-6.

49. Lowe SW, Bodis S, McClatchey A, Remington L, Ruley HE, Fisher DE, Housman DE, Jacks T. p53 status and the efficacy of cancer therapy in vivo. Science. 1994;266:807-10.

50. Smith ML, Chen I-T, Zhan Q, O'Connor PM, Fornace AJ Jr. Involvement of the p53 tumor suppressor in repair of UV-type DNA damage. Oncogene. 1995;10:1053-9.

51. Agarwal ML, Taylor WR, Chernov MV, Chernova OB, Stark GR. The p53 network. J Biol Chem. 1998;273:1-4.

52. Lowe SW, Lin AW. Apoptosis in cancer. Carcinogenesis. 2000;21:485-95.

53. Westfall MD, Mays DJ, Sniezek JC, Pietenpol JA. The $\Delta$ Np63a phosphoprotein binds the p21 and 14-3-30 promoters in vivo and has transcriptional repressor activity that is reduced by Hay-Wells syndromederived mutations. Mol Cell Biol. 2003;23:2264-76.

54. Wang $X$, Gorospe M, Huang Y, Holbrook NJ. p27 $7^{\text {Kip } 1}$ overexpression causes apoptotic death of mammalian cells. Oncogene. 1997;15:2991-7.

55. Ford JM, Hanawalt PC. Expression of wild-type p53 is required for efficient global genomic nucleotide excision repair in UV-irradiated human fibroblasts. J Biol Chem. 1997;272:28073-80.

56. Roos WP, Kaina B. DNA damage-induced cell death by apoptosis. Trends Mol Med. 2006;12:440-50.

57. Jekimovs C, Bolderson E, Suraweera A, Adams M, O'Byrne KJ, Richard DJ. Chemotherapeutic compounds targeting the DNA double-strand break repair pathways: the good, the bad, and the promising. Front Oncol. 2014;4: 86.

58. Karanja KK, Cox SW, Duxin JP, Stewart SA, Campbell JL. DNA2 and EXO1 in replication-coupled, homology-directed repair and in the interplay between HDR and the FA/BRCA network. Cell Cycle. 2012;11:3983-96.

59. Nimonkar AV, Ozsoy AZ, Genschel J, Modrich P, Kowalczykowski SC. Human exonuclease 1 and BLM helicase interact to resect DNA and initiate DNA repair. Proc Natl Acad Sci U S A. 2008;105:16906-11.

\section{Ready to submit your research? Choose BMC and benefit from:}

- fast, convenient online submission

- thorough peer review by experienced researchers in your field

- rapid publication on acceptance

- support for research data, including large and complex data types

- gold Open Access which fosters wider collaboration and increased citations

- maximum visibility for your research: over $100 \mathrm{M}$ website views per year

At BMC, research is always in progress.

Learn more biomedcentral.com/submissions 